\title{
The challenges to discussing emotionally loaded stories in Finnish teacher education
}

\author{
Erkki T. Lassila, Katri Jokikokko, Minna Uitto and Eila Estola \\ Faculty of Education, University of Oulu
}

Erkki T. Lassila, Faculty of Education, P.O. Box 2000, 90014 University of Oulu, Finland, email: erkki.lassila@gmail.com ; Katri Jokikokko, Faculty of Education, P.O.Box 2000, 90014 University of Oulu, email: katri.jokikokko@oulu.fi ; Minna Uitto, Faculty of Education, P.O. Box 2000, 90014 University of Oulu, Finland, email: minna.uitto@ oulu.fi; Eila Estola, Faculty of Education, P.O.Box 2000, 90014 University of Oulu, email: eila.estola@oulu.fi

Correspondence concerning this article should be addressed to Erkki Lassila, Faculty of Education, P.O. Box 2000, 90014 University of Oulu, Finland. Phone (+358)40-3517253, E-mail:

erkki.lassila@gmail.com 


\begin{abstract}
It has been increasingly acknowledged that emotions are a significant dimension in teachers' work and professional development, and an inseparable part of reflection promoted in the research-based teacher education. However, at the same time the difficulty of prompting student teachers to reflect on their emotions in teacher education has been recognised. This article focuses on this difficulty by examining how emotionally loaded stories about teachers' work were dealt with by soon-tograduate Finnish student teachers attending peer group mentoring sessions. We illustrate this group level phenomenon (the challenge of discussing emotionally loaded stories) through the examples provided by one of the participants, Hannele (pseudonym). Our results revealed that emotionally loaded stories in this peer group were often responded to with laughter and humour or via masking or silencing. Participants seemed to avoid deeper emotional reflection on uncertainty related to oneself and to the teaching profession, therefore maintaining an image of a proper (student) teacher. Our results have implications for both peer group mentoring and pre-service teacher education.
\end{abstract}

\title{
Introduction
}

In this article, we consider how Finnish student teachers discuss emotionally loaded stories in a peer group mentoring sessions and connect this discussion to internationally widely acknowledged concern of applying theory into practice in teacher education (e.g. Zeichner 2010). In any country and context there are cultural expectations on what a proper teacher is supposed to be like (Lassila 2017). In Finland the teacher is expected for example to be an independent professional and typical teacher "type" embodying the following traits: empathy, reflectivity, sociability, self-confidence, positive predominant mood, determinacy, activity (Lanas \& Kelchtermans 2015). Many of these expectations are also connected to professional norms stemming from teacher education. Instead of practically oriented teacher training programs that are common in many countries (e.g. Hammerness, Darling-Hammond, Grossman, Rust, and Shulman 2005), in Finland being academic, scientific and research-based are common features of policy, curricula and practices related to teacher education, which always takes place in universities (Silander and Välijärvi 2013; Sitomaniemi-San 2015). The issues raised here are to some degree tied to the specific context of Finnish teacher education and may not be applicable to other systems as such. However, we believe that our theoretical conclusions provide food for thought to anyone interested about the role of emotions in teacher education.

The notion of teacher as researcher is a core organizing principle of Finnish teacher education and is commonly invoked in conversations concerning teacher ideals and curricular- 
pedagogical models (Sitomaniemi-San 2015). An ability to reflect on the theory and practice of teaching and learning is therefore central to Finnish teacher education (e.g. Silander and Välijärvi 2013). However, while rational reflection and argumentation is often emphasised (Westbury et al. 2005, Toom et al. 2010), the role of emotions in learning and in teachers' work is relegated to a footnote. The present research highlights the role of emotions in research-based teacher education by means of an example from Finnish teacher education, exploring how emotions were dealt with by students who were soon to graduate and who attended peer group mentoring sessions. We illustrate the emotional discussions in this group by focusing one participant, Hannele (pseudonym).

In recent years, emotions have increasingly been acknowledged in the educational research literature as an important part of teachers' work. The teacher-educator's ability to properly address students' emotions has also been emphasised as a key issue in teacher education (Kelchtermans and Deketelaere 2016; Uitto, Jokikokko and Estola 2015). We also understand teachers' work as relational and moral by nature, and as inherently informed by emotions (Hargreaves 1998, 2000; Kelchtermans 2009; Nias 1996; Zembylas 2007). There is evidence that emotionally intense nature of beginning teachers' work (Kelchtermans and Ballet 2002) and a lack of proper organisational support in respect of emotional issues influences beginning teachers' decision to leave the profession (Hong 2010; Le Maistre and Pare 2010). Student teachers are known to experience a wide range of emotions during their studies (Anttila, Pyhältö, Soini and Pietarinen 2016), affecting both their learning during teacher education and subsequent experiences in the field. For this reason, as argued by Eren (2013) and others, the emotional life of future teachers needs to be acknowledged and understood. Earlier studies have reported that discomforting emotions can block, diffuse and distract students' transformation and learning processes or serve as a potential learning resource (Boler 1999; Zembylas 2008, 2012). Either way, emotions need to be properly addressed in pre-service teacher education by providing opportunities for student teachers to reflect on the emotional aspects of their experiences and by helping students to deal effectively with those emotions. In this regard, established practices, pedagogical tools and relevant research remain limited (Estola, Heikkinen and Syrjälä 2014).

Narratives are known to be effective as a means of making sense of one's experiences, including the emotional dimension (Kelchtermans 1996; Noddings 1996), but there is insufficient knowledge about the connection between emotions and narration, especially in the context of teacher education. Therefore, our research question is: How are emotionally loaded stories about teachers' work dealt with by soon-to-graduate student teachers in the context of peer group mentoring? The findings contribute to knowledge of peer group mentoring processes in both teacher education and in the field, providing new insights into possibilities and challenges, 
including the development of research-based teacher education to better acknowledge the role of emotions in student teachers' studies and professional growth.

\section{Theoretical framework}

\subsection{Emotions in teachers' work and teacher education}

We view teaching as a profoundly moral profession, with human relationships at its heart (Estola 2003; Hansen 1998; Noddings 2001). As a key component of these relationships, emotions are at the core of the teaching profession and of students' learning processes (Hargreaves 1998). According to Zembylas (2005), the processes of teacher identity formation (and so of professional learning) are fundamentally entangled with teachers' emotions; these emotions inform and define teachers' professional and personal identities, and identity in turn guides and shapes teachers' emotional decisions and reactions (Shapiro 2010). Following Zembylas (2004) and Kelchtermans (2005), we understand emotions not only as an individual's private and psychological experience but as social by nature, influenced by the norms of the surrounding culture and by teachers' interactions with their professional environment.

Although emotions are increasingly acknowledged as an important part of the work, the image of teachers as rational professionals who must manage and control both their own emotions and those of their students still seems to prevail among pre-service and in-service teachers and teacher educators (Uitto, Kaunisto, Syrjälä and Estola 2015; Boler 1999). Teaching is among those professions characterised by particularly strong cultural and institutional expectations, although these are often implicit (Gross and Thompson 2007). Zembylas (2005) studied the norms conditioning teachers' emotional expression and labelled these as emotional rules. These rules are embedded in the cultural expectations, social standards and professional norms of teaching and so influence teachers' professional identity (Shapiro 2010; Zembylas 2004). As well as dictating what kinds of emotions teachers should express or suppress, emotional rules also prescribe the kinds of identities they should or should not embrace in their work (Zembylas 2004). In this way, maintaining and controlling different emotions becomes an integral part of teachers' identity work, in their efforts to inhibit, generate and manage their emotions according to normative beliefs and expectations about the teaching profession (Isenbarger and Zembylas 2006).

It is also possible that implicit emotional rules are established as part of the group culture. In the present research, shared meanings are mostly tied to what participants of the peer group understood as part of being a (student) teacher in the Finnish context, as well as to the culture formed whenever a group gathers. The goal for the student teachers was to share their ideas and 
expectations about their future work. Maintaining harmonious and beneficial relations with other members of the community and preserving the cohesion of the group was seen to depend on controlling the emotional outputs of oneself and others. This kind of emotional management typically happens in professions where social interaction plays an important role and expression of positive emotions is expected (Hargreaves 1998).

Teacher education can play a significant role in helping students to recognize and question the norms and related emotional rules in teacher's work, and to deal with their own emotional state. The development of teachers' professional identity and growth requires awareness of their own emotional states, along with an ability and willingness to reflect on and learn from their emotions (Timoštšuk and Ugaste 2012). A number of studies have looked at methods for prompting student teachers to reflect on their emotions as part of their experience in teacher education (Kelchtermans and Deketelaere 2016). Suggestions include the use of journals or diaries that capture the range of student teachers' emotional experiences - for instance, during their teaching practice (Nichols, Schutz, Rodgers and Bilica 2016) — as well as autobiographical reflection and storytelling (Kelchtermans 1996, Noddings 1996). Other methods such as art, drama and sociometric techniques can also provide diverse perspectives on emotions, including the significance of embodiment (Uitto et al. 2015, Burton 2012, Schonmann and Kempe 2010).

\subsection{Finnish student teachers and peer group mentoring}

In Finland, all teachers from early childhood education to upper secondary school are educated at university level. Completion of a five-year master's degree is required for primary and secondary teacher qualification; early childhood teachers need to complete a three-year bachelor's degree, but many also undertake supplementary master's studies. Although teaching is widely acknowledged in Finland as an autonomous profession that draws on one's own unique personality and a wide variety of approaches, there remains a tendency to conform to and strive for the prevailing teacher ideal (cf. Vuorikoski and Räisänen 2010). In their research of Finnish student teachers, Lanas and Kelchtermans (2015) found that even in an educational system free of official normative evaluations for teachers, norms remain implicit in the 'lived curriculum' of teacher education. In the process of internalising these norms, student teachers efficiently reproduce what is expected or perceived as appropriate for good teachers in the social and cultural environment. Lanas and Kelchtermans identified four normative images: 1) 'being motivated and investing effort', 2) 'representing the teacher type', 3) 'adhering to the right values' and 4) 'being willing to shape one's self'. 
In the Finnish system, there is no official induction or mentoring period for beginning teachers; although mentoring is acknowledged as beneficial for beginning teachers (Aspfors and Bondas 2013), it is not yet systematically practised, other than on a voluntary basis in peer groups. The relevant literature highlights a need during the induction phase for activities that focus on sharing and listening to others (Cohen 2010; Heikkinen, Tynjälä and Jokinen 2012; Ingersoll and Strong 2011). One example of such an activity is peer group mentoring, which usually involved inservice teachers. However, in this article the peer group mentoring is done within the context of teacher education. One of the goals of peer group mentoring to ensure that everyone is accepted and experiences related to work are heard (Kaunisto, Estola and Niemistö 2012). This reciprocal sharing of experience is seen to enhance professional development, work motivation, burnout prevention and coping with the demands of the work (Boyle, Topping, Jindal-Snape and Norwich 2012; Le Cornu 2005; Wang and Odell 2007). There is also evidence that the peer group enables teachers to relieve some of their emotional burden, gaining a deeper understanding of themselves through reflections opened up by narratives told by oneself and others (Kaunisto, Estola and Leiman 2013). Although the potential of peer group mentoring for supporting teachers' professional learning has been acknowledged (Heikkinen et al. 2012), some challenges have also been noted (Korhonen et al. 2015). For example, disconnection between the theory and practice in students' discussions (leading to limited depth of reflection) and unequal relationships between participants have been identified as possible problems in peer group mentoring (Hobson et al. 2009; Korhonen et al. 2016). The present research examines the challenges of dealing with the emotionally loaded narration required for emotional reflection.

\section{Methodology}

Methodologically, our study falls within the field of narrative approach. Based on this approach, we understand the stories people tell as essential way to organise knowing and social reality (Bruner 1986; Spector-Mersel 2010). Narratives are strongly reflective, and storytelling can be understood as a significant practical tool for teachers' professional development and for the construction of teacher identity (Estola, Kaunisto, Keski-Filppula, Syrjälä and Uitto 2007). Additionally, stories always have a communicative purpose, in that the series of events they describe are always charged with different meanings that the narrator seeks to relay to the listener (Riessman 2008). For this reason, listeners' expectations and other contextual factors play an important role in what is told, and how.

The research context in our study was an optional peer group mentoring course for soon-to-graduate student teachers from different teacher education programmes in a Finnish teacher education institution. The course consisted of six peer group sessions, during which the students 
could talk about issues such as what kind of teachers they were becoming, how to engage with students, parents and colleagues and the many emotions embedded in teachers' work. Ten student teachers (nine female and one male) participated in the course, which took place in the fall of 2012. Seven of the students were from primary school teacher education program and three from early childhood teacher education program. The course was open also for prospective secondary school teachers, but in the end no one of them was able to take part in the group. One of the ten participants who attended the course was Hannele, whose stories we decided to focus on in this article to illustrate the emotionally loaded discussions in the group. The peer group was led by two experienced primary school teachers, who had previous experience of mentoring in-service teacher (see 2.2). They led the discussion but did not offer direct answers to questions and did not impose their own point of view. The first author was present at the sessions but did not take part in the actual discussions. Instead, he video-recorded the sessions, making field notes during and after the sessions. The sessions, each lasting for two hours, were held in a primary school classroom. The basic structure of the sessions was always similar, starting with a free discussion during which every student teacher spoke about their past week and current feelings. During the sessions, various methods (such as small sub-groups) were used to stimulate discussion and to provide opportunities for telling about one's experiences and expectations and concerns about the future work.

Research material comprised 1) transcriptions of the six video-recorded peer group sessions (150 pages of text in 12-point font); 2) diaries written by all ten participants after the sessions and 3) 'later written reflections' from one group participant, Hannele, on her experience of being in the peer group. Participants' anonymity was secured by changing all names and removing details that might help to identify the participants. We sought all participants' permission to use both the videorecordings and their diaries, advising them that they could withdraw from the research at any time. Everyone gave us their consent.

Our original research interest centred on emotional narration about significant others (students, colleagues, parents). The analysis started inductively, with several readings of the transcripts of the videos and the diaries written by the student teachers. During these readings, we noticed that there was less emotionally loaded narration in the peer group sessions than expected, but some students reflected on the (emotional) themes more profoundly in their diaries.

One participant in particular, Hannele, captured our attention, as she very often shared emotionally loaded stories. The first author (who attended the peer group sessions) observed her often talking about feelings of insecurity and vulnerability, which she also reflected thoroughly in her diaries. We decided to invite Hannele to reflect with us both on the process of being in the group and on selected episodes that we wanted to hear more about. Hannele watched some of the videorecordings, reflecting on the experience a few months after the original sessions. We also asked her 
to write down her thoughts ('later written reflections'). Hannele's most striking observation was that she and the rest of the group talked in different emotional tones on the video as compared to the emotions that she wrote about in her diary. Hannele's own emotional experience was not reflected in the video or was not dealt with in the group narration. Furthermore, the others did not pick up on the emotion she had wished to convey, or the response of the group was somehow unexpected. Based on this observation, we decided next to focus exclusively on Hannele's diary, her later reflections and those episodes in the transcripts of the video recorded peer group sessions that Hannele referred to in her diary.

We then conducted a simultaneous analysis of the transcripts of the peer group episodes and Hannele's descriptions of those episodes in her diaries and later reflections. We found discrepancies between how something looked like in the transcripts and what Hannele wrote in her diary or how she later reflected on it. Our next step was to examine more closely what might lie behind these discrepancies by focusing on the utterances during the group discussion (Gubrium and Holstein 2009, p. 45) to identify the 'factors that incite or activate narrative production or that curtail storytelling', focusing mainly on the curtailing aspect while taking account of the conditions under which the stories were produced. Through this we found the following ways of the group participants' responding to emotionally loaded stories: 1) laughter and humour, 2) silencing and 3) masking.

\section{Findings}

\subsection{Laughter and humour}

One of the ways that the participants responded to emotionally loaded stories was to resort to laughter and humour. A prime example comes from the second session during which participants recalled their childhood teachers, after a discussion of how schools used to be like factories, Hannele shared a long story about one of her own former male teachers in elementary school, a story which was emotionally loaded. In her later reflections, Hannele noted how she had intended this as a more sombre story and was therefore surprised when the group reacted to it with laughter and saw it as humorous.

Hannele: I was a good gal, so it was easy to give me good grades [laughing] ... mostly good memories, at least about "normal" teachers [laughing]. During junior high, we had some really strange ones [...] During elementary school, everyone talked about how there was one really strict male teacher who then became our homeroom teacher. Everyone was afraid and 
anxious, but after meeting him, I was like "It's not so bad", and we got along fine. He disciplined the energetic boys quite strictly, but there was humour and warmth to him...but he did not really allow anyone to become close... He always shook everyone's hand in a really manly manner when handing out record cards. But then during the sixth grade, the last year final party, I remember going to the school kitchen, and there was no one but this teacher. I think I went to just say hi, when suddenly he hugged me [sounding really happy], and it was really wonderful. He hugged me so that my feet left the ground [the group laughs].

Hannele describes how she relied on this teacher even after graduation, asking for his advice, and how some years later her younger sister started going to the same school.

Hannele: I was at junior high when my sister was in fourth grade. The teacher had already retired. There was real chaos in the little school when two teachers who did not really even teach came to the school. Obviously, as an older sister, I was worried, so I wrote to my old teacher, pouring my heart into text, telling him about the intolerable situation with incompetent teachers that my own little sister was experiencing at the same school, asking and hoping if he could help in some way [laughing and everyone else joining in].

Päivi [student teacher]: Did you send it?

Hannele: Yes, I did.

[roaring laughter continues]

Päivi: It was not just that you wrote and expressed your...

Hannele: I sent it and got an Easter postcard in return mail ...

[laughter]

Päivi: My condolences.

The caring and pedagogical love signified by the hug from the teacher and Hannele's reaching out to him when in need made this story emotionally loaded, and it is easy to imagine other people having a similar bond with their own teacher. If one reads the transcript without the laughter inserts, 
this is the story of a young girl and the close relationship with the teacher she said she grew to really like, and it does not seem that funny. In her later reflections, Hannele herself wrote:

I did not indeed have any intention of telling the story in that way, and I did not think of that memory of the teacher as funny to begin with. But, in a way, the reaction of the group to the story made me see the humorous side to it, and I joined in the laughter. (Later written reflections)

Exploring these vulnerabilities by taking the stories at (textual) face value might have forced listeners to Hannele's story to confront more delicate and possibly uncomfortable emotions head on. Her story also echoes the deep emotional bond (pedagogical love) that sometimes forms between a student and a teacher. While such relationships are discussed during teacher education and are accepted as a natural part of the profession, the dominant view is still of the teacher as a somewhat cool and distant professional (see Hargreaves 2000), and student and beginning teachers are sometimes warned not to get too close to their pupils (Förbom 2002). It is possible that some expectations concerning how a teacher should tell about themselves were broken, or that a more serious interpretation of the story might have forced those listening to reflect on emotionally loaded memories of their own.

Avoidance is understandable, but why respond to a serious story with laughter in the first place? According to Francis (1994), humour and laughter serve many functions in human communication and interaction. While humour is used as a bonding device, generating positive sentiments among group participants, it can also act at a personal level as a way of releasing accumulated tensions and relieving emotional stress by diverting attention from threatening and stressful aspects of a situation (Francis 1994). In discussion groups, self-reflection and exploration can be seen to cause anxiety, and difficult topics that occasionally arise are avoided, either by responding with laughter or by directing the discussion towards other topics (Franks, Watts and Fabricius 1994). In a peer group, humour and laughter can serve many purposes, as a way of managing others' emotions, restoring or strengthening emotional norms or amusing oneself and others. Framing a given story as humorous provides a distance that allows both teller and listeners to alter their emotional response to one that is more culturally and contextually acceptable (Francis 1994). 


\subsection{Masking}

Another way of responding to emotionally loaded narration, masking is understood here as downplaying or hiding negatively appraised emotions such as anger, frustration or anxiety to maintain the image of 'a proper teacher' (Kelchtermans 1996), who is expected to express caring, enthusiasm and other positively appraised emotions and attitudes in his or her work (Hargreaves 1998). Our example of masking is taken from the first session, when the mentors introduced a mirror exercise. In this exercise, the participants were asked to look into a mirror and to imagine the future it revealed. They were asked to think of an ideal situation-something that they wished to be or qualities they wished to have as future teachers. Hannele recalled this exercise in her written reflections as a situation she found to be very emotional loaded:

The mirror exercise felt really personal and even important to me. I was in a very emotional state the whole time, and breaking down in tears was a real possibility. My level of insecurity was what caused tears of relief when I heard the reassuring and encouraging words of the mentors - that despite my lack of experience, I also have a lot to give. (Later written reflections)

In the actual session, Hannele talked about what she saw in the future mirror in this way:

I thought of moments... what is most important for me... like having a normal day at work and then feeling good tiredness and satisfaction about the day's accomplishments [...] As a student teacher, I have had problems finding satisfaction in my everyday work.

The first author, who was present at the session, did not notice any strong emotional response to this or other episodes, nor did the video-recording of the session indicate any such emotion occurring. However, while even Hannele herself wrote nothing in her diary immediately afterwards, the extract suggests that this exercise was emotionally meaningful for her, and the tears of relief were a way of describing what she felt inside rather than recollecting what had actually happened. In her reflections, Hannele describes how she was actually masking her true feelings of insecurity, writing that she was close to tears. It is likely that during the early stages of the peer group, when the participants were still getting to know and trust each other, strong emotional expressions were seen as something that should be played down in order to avoid standing out or being misunderstood. The aim, then, seemed to be to present oneself as a capable future teacher (through self-image management) and not to disrupt group cohesion building. Although the participants were not yet 
full teachers, it can be argued that they possessed a certain image of what a (good) teacher is like, having been acculturated to this image both in their private lives through stories circulating in the Finnish culture (see Mitchell and Weber, 1999) and in teacher education. It is not unreasonable, then, to infer that student teachers felt a need to perform emotional labour to cope with expectations about presenting themselves as certain kinds of teachers during the peer group sessions. This is apparent in Hannele's words above, where her concern about showing others her insecurity caused her to hide it.

The next example of masking as a way of responding to emotionally loaded stories comes from the beginning of the third session, where Hannele was talking about her various experiences since the last session. Her narration is full of themes that touch on the teacher's vulnerable side, such as getting critical feedback and feeling down, and are therefore by their nature quite emotionally loaded.

Well, you see, I had a calm and stress-free feeling like that last week, but then I stumbled down from there to the complete opposite, like, you know... I felt as if someone had whacked me in the head... Yesterday, I got really critical feedback from the music school sessions that I teach. Now I'll have a tough time recomposing myself to go there next week... again and [sighs]...or a bit like... it's... struggling whether to just give up now or only after Christmas... I'm certainly not having the spring semester but... a bit like that ... Having a slightly bad day...but then it was interesting that when I came here, my day got instantly better, when I saw you [talking to one member of the group, a bit of laughing] and then you fell over [more laughter]... Somehow I got the feeling that I was coming here, and when I sat down, I felt a lot more calm...it's like this today.

Later, when talking about this particular moment in her reflections, Hannele writes:

I did not cry or in other ways show any significant sentimentality when telling how I had been, even though I had been crying my eyes out during the morning that day. I had been feeling blue, disappointed in myself and afraid of sinking back after so many good weeks. (Later written reflections)

Despite telling briefly about the unpleasant things that had happened since the last session, it appears that Hannele had managed her emotions to avoid displaying her negative emotions too openly in the peer group. She also remarked on how her spirits had risen when she met some of the 
group participants before the session started. She wrote in her later reflections that her anxiety about the music school stopped and she had found something else to occupy her mind with.

\subsection{Silencing}

In our research material, silencing involved indirect avoidance of telling emotionally loaded stories -for example, despite being so invited by one participant, other group participants did not share a similar story or continued to narrate on the same theme. It is possible that participants simply had nothing similar to share or for whatever reason wanted to keep such things hidden, but our examples suggest otherwise. One example of responding with silence is taken from the third session, where participants were talking about different future scenarios. Hannele brought up yet another emotionally loaded story, which related to relationships in the workplace.

Armi [mentor]: You were envisioning a future where everything goes wrong...

Hannele: The aspect of completion was not brought up by me... I thought of the conflictridden work environment and bullying...that if nothing matches...You're kind of alone with your own ideas, and then they [colleagues] just don't even try to understand or to meet you halfway. In a way, you just get beaten down, being scum for thinking like that... Going to do the early childhood educator's job, you're quite afraid and worried what kind of group you'll end up with. Even during the substitute teaching gigs, you notice how different the workgroups are and how the atmosphere can change between groups inside the same day care centre. Yeah... you tend to get nervous...

Päivi [student teacher]: Is it then about the leadership at all...could it affect the atmosphere in any work environment?

The discussion continued with Hannele's long comment about how leaders do play a part but that how the work environment develops is ultimately down to the people —in this case, the early childhood teachers. She said she had worked in many day care centres and had therefore seen many different work communities:

There was one place where I liked the leader's way of doing things and liked being there, but there was one group where I always felt like there is no way I can really express myself ... I always felt like "why don't we ever do anything around here? 
She talked about being frustrated about the situation and feared that being in a similar situation again in the future would lead to conflicts, which made her a bit anxious.

No one joined in with their own experiences or took up this opening. The discussion continued, with one of the participants and the mentors bringing the discussion back to a more general area, and then the session moved on. Hannele wondered in her diary why no one had picked up on this opening, which she considered very important. Later, commenting on the third session, she wrote:

If I tried to change the practices and do the work for my own part the way that I want, I would run into conflicts with others all the time. My statement was quite long, but no one really answered it, which on one hand makes me a bit puzzled. Were my fears in way then justified...that if things like that happen, it's very unfortunate, but no one could come up with ideas on how to resolve the situation. Or were we just running out of time? (Later written reflections)

Hannele's text shows that she was disappointed that no other group participants offered alternative solutions to her problem scenario as she had expected. They did not even properly acknowledge or recognise the issue she was raising about being voiceless within the work environment and experiencing the tension of wanting to change while knowing that to do so would probably lead to a conflict. It seems likely that no one wanted to admit that there are no easy solutions to problematic relationships in the work community - a problem that everyone might soon be facing - and that it felt more comfortable to just silence the emotionally loaded story.

While silence or silencing is often unwanted, the next example from Hannele illustrates that this is not always the case. During the third session, the participants were divided into small groups, each of which was asked to envision different possible future scenarios as teachers: 'abysmal', 'normal' and 'ideal'. Hannele was part of the abysmal future group. As in the case of possible problems with colleagues, no one wanted to paint too bleak a picture of their possible future. To get past this and draw out some ideas, the mentors finally asked what they would do differently if they had the chance, and how they would react in a really difficult situation. Hannele said that she had a thought so depressing that she had at first decided not to say it, but she ended up telling it: 'I would have stayed in bed at home', she said, laughing. To this the mentor replied: 'Good... would you even call the workplace to tell that you won't be coming to work today?' After that, the discussion moved swiftly to another participant and topic. Here, silence appeared as an instant change of topic, with no one commenting on or following the notion. In her later written reflections, Hannele wrote: 'Luckily, no one really continued from this opening because I knew that I was looking for hope 
myself and I did not mean to add to an atmosphere of despair'. In addition, she wrote that she had intentionally narrated the anecdote as humorous even though there was a grain of truth in it. Her reflections showed that silence can also have a positive effect from the perspective of the teller. In both of the above cases, silence seems a subtle way of managing the emotional narration and subsequently the emotions in the group.

\section{Discussion}

This research focused on how emotionally loaded stories were dealt with in soon-to-graduate student teachers' peer group mentoring sessions, approaching them through stories shared by one of the participants. The results indicate that sharing emotionally loaded stories is challenging even when the situation is planned for open and safe for discussions. We identified three kinds of ways of responding to emotionally loaded stories. These were based on how the other participants responded to Hannele's emotionally loaded stories. Firstly, laughter and humour were used to lighten the tone of the narration or to lessen a story's seriousness. Secondly, there was masking, which is understood here as hiding or downplaying negative emotions. Finally, silence was used to move or force the discussion into more comfortable areas. There seemed to be a limit to how much uncertainty or vulnerability student teachers were willing to admit to, and laughter, masking and silence were used to avoid compromising the group's cohesion or one's own role as a member, and to adhere to the image of a 'proper' teacher. It seemed better to avoid deeper (emotional) reflection on uncertainty related to oneself and to the teaching profession (see also Heikkinen et al. 2016).

As one of the aims of research-based teacher education is to educate reflective practitioners, it is worth of asking, how successful the programme is in this regard. The participants were not yet quite full teachers but neither were they just students. Our findings support the view that student teachers, at least implicitly, consider their work to be more rationally oriented, even when given scope and encouragement to explore its emotional dimension. The liminal stage set its own conditions for how student teachers felt they should narrate themselves — how to tell oneself as a teacher in a situation characterised by feelings of worry and uncertainty about one's ability to handle demanding professional realities.

Instead of trying to make empirical generalizations based on the research material, this article aims to provide new insights to theoretical discussions on dealing with emotions in teacher education and especially in peer group mentoring. Despite its limited scope, our research provides some useful insights into challenges that can emerge in peer groups. Approaching the emotionally loaded discussions in the group through a single participant's story, we were able to do an in depth 
analysis that would have been unattainable had we chosen to examine the whole group. Even though the research material was collected five years ago, the Finnish teacher education system has not changed significantly in the meantime and emotions in teaching and teacher education are still rather marginalized. Therefore, our viewpoints can be considered to be still very relevant. Also, the passage of time has a meaning from the ethical perspective as the students and mentors are now harder to identify.

As reflection including emotions is important for student teachers' development (Kelchtermans and Deketelaere 2016), the ways how to encourage it should be looked for. Our findings suggest that although peer groups can support reflection, it does not happen automatically. Compared to the open themes of discussions as in our study, it has been suggested that structuring peer group sessions around clearly defined topics may help participants to feel safer in addressing difficult topics (Franks et al. 1994). The introduction of these kind of more general examples in peer group sessions may help participants to distance themselves from the original situation and (possibly threatening) associated emotions. It also seems important to give student teachers an opportunity to reflect their thoughts in various ways after such sessions. In the present study, we could clearly detect a disparity between Hannele's utterances in the group and what she wrote in her diary and later reflections. While students may find writing more demanding than group discussion (Naysmith and Palma 1998), it undoubtedly offers more time to ponder and arrange one's thoughts, and to relate those thoughts to the relevant academic literature. To facilitate deeper reflection (both emotional and rational), we propose that peer group mentoring sessions and similar activities in teacher education should be paired with other forms of reflection such as reading, writing and storytelling.

The heavy emphasis on rational reflection in research-based teacher education may neglect or hide emotional issues as a natural part of learning, studying and teaching. Teacher educators should actively seek to help students not only to accept but to cope constructively and reflectively with a range of emotions (Liljeström, Roulston and deMarrais 2007). The central issue is how to enhance professional and academic reflection and learning by linking rational and emotional reflection in a meaningful way.

\section{Acknowledgements}

The writing of this article was funded by the Academy of Finland (Disentangling the emotional dimension in beginning teachers' work (EMOT) project, grant no. 265974)

\section{Biographical notes}


Erkki T. Lassila, PhD, at the University of Oulu. His doctoral thesis discussed the tensions in beginning teachers work. His research interests are in the relational, cultural and emotional dimensions of teachers' work and narratives concerning education.

Katri Jokikokko,PhD, is a post-doctoral researcher in the Faculty of Education at the University of Oulu. Her doctoral thesis discussed teachers' intercultural learning and competence. Her current research interests are related to emotional dimension in beginning teachers' work and emotional dimension in intercultural learning.

Minna Uitto, $\mathrm{PhD}$, is a post-doctoral researcher at the Faculty of Education at the University of Oulu, Finland. Her research interests focus on the relationships and emotions of teachers' work.

Eila Estola, $\mathrm{PhD}$, is Professor of Early Childhood Education at the Faculty of Education, University of Oulu. Her main research interests deal with moral and emotional aspects

\section{References}

Anttila, H., P. Pyhältö, T. Soini, and J. Pietarinen. 2016. "How Does it Feel to Become a Teacher? Emotions in Teacher Education.” Social Psychology of Education 19: 451-473.

Aspfors, J., and T. Bondas. 2013. “Caring about Caring: Newly Qualified Teachers' Experiences of their Relationships within the School Community." Teachers and Teaching: Theory and Practice 19: 243-259.

Boler, M. 1999. Feeling Power. New York: Routledge.

Boyle, C., K. Topping, D. Jindal-Snape, and B. Norwich. 2012. "The Importance of Peer-Support for Teaching Staff when Including Children with Special Educational Needs." School Psychology International 33: 167-184. doi:10.1177/0143034311415783

Bruner, J.1986. Actual minds, possible worlds. Cambridge MA, Harvard University Press

Burton, B, 2012. Peer-teaching as a strategy for conflict management and students' re-engagement in schools. Australian Educational Researcher, 39 (1), 45-58.

Chang, M.-L. 2009. “An Appraisal Perspective on Teacher Burnout: Examining the Emotional Work of Teachers.” Educational Psychological Review 21: 193-218.

Clandinin, D. J., and F. M. Connelly. 2000. Narrative Inquiry. Experience and Story in Qualitative Research. San Francisco: Jossey-Bass Publishers. 
Cohen, J. 2010. “Getting Recognised: Teachers Negotiating Professional Identities as Learners through Talk." Teaching and Teacher Education 26: 473-481.

Elbaz-Luwisch, F. 2005. Teachers' Voices: Storytelling and Possibility. Greenwich: Information Age.

Eren, A. 2013. 'Uncovering the Links between Prospective Teachers' Personal Responsibility, Academic Optimism, Hope, and Emotions about Teaching.” Social Psychology of Education 17 (1): 73-104.

Estola, E. 2003. "Hope as Work: Student Teachers Constructing Their Narrative Identities." Scandinavian Journal of Educational Research 47: 181-203.

Estola, E., Heikkinen, H. \& Syrjälä, L. 2014. Narrative pedagogies for peer groups. In: C. Craig \& Orland-Barak, L. (Eds.) International Teacher Education: Promising Pedagogies (Part A) Advances in Research on Teaching. Bingley, UK Emerald Group Publishing Limited Vol. $22,159-176$.

Estola, E., Kaunisto, S.-L., Keski-Filppula, U., Syrjälä, L. and Uitto, M. 2007. Lupa puhuakertomisen voima työssä ja arjessa. Jyväskylä: PS-kustannus.

Francis, L. E. 1994. "Laughter, the Best Mediation: Humor as Emotion Management in Interaction." Symbolic Interaction 17 (2): 147-163.

Franks, V., M. Watts, and J. Fabricius. 1994. "Interpersonal Learning in Groups: An Investigation.” Journal of Advanced Nursing 20: 1162-1169.

Gross, J., and R. A. Thompson. 2007. “Conceptual Foundations for the Field.” In Handbook of Emotion Regulation, edited by J. J. Gross, 3-24. New York: Guilford.

Gubrium, J. F., and J. A. Holstein. 2009. Analyzing Narrative Reality. London: Sage.

Hammerness, K., Darling-Hammond, L. Grossman, P., Rust, F., and Shulman, L. 2005. "The design of Teacher Education Programmes". In Preparing Teachers for a Changing World. What Teachers should learn and be able to do, edited by L. Darling-Hammond, and J. Bransford, 390-441. San Francisco: Jossey-Bass.

Hansen, D. T. 1998. "The Moral is in the Practice.” Teaching and Teacher Education 14: 643-655. Hargreaves, A. 1998. "The Emotional Practice of Teaching." Teaching and Teacher Education 14: 835-854.

Hargreaves, A. 2000. "Mixed emotions: teachers' perceptions of their interactions with students." Teaching and Teacher Education 16, 811-826.

Heikkinen, H. L. T., H. Jokinen, and P. Tynjälä, eds. 2012. Peer group Mentoring for Teacher Development. New York: Routledge.

Hobson, A.J., Ashby, P., Malderez, A., and Tomlinson; P.D. 2009. "Mentoring beginning teachers: What we know and what we don't." Teaching and Teacher Education 25, 207-216. 
Hong, J.Y. 2010. 'Pre-service and beginning teachers' professional identity and its relation to dropping out of the profession." Teaching and Teacher Education 26(8), 1530-1543.

Hochschild, A. R. 1983. The Managed Heart: Commercialization of Human Feeling. Berkeley: University of California Press.

Hyvärinen, M. 2008. “Analyzing Narratives and Story-telling.” In The SAGE Handbook of Social

Research Methods, edited by P. Alasuutari, L. Bikman and J. Brannen, 447-460. London:

Sage Publications.

Ingersoll, R. M., and M. Strong. 2011. "The Impact of Induction and Mentoring Programs for

Beginning Teachers: A Critical Review of the Research." Review of Educational Research 81: 201-233. doi:10.3102/0034654311403323

Isenbarger, L. and M. Zembylas. 2006. "The emotional labour of caring in teaching.” Teaching and Teacher Education 22, 120-134.

Kaunisto, S.-L., E. Estola, and R. Niemistö. 2012. “Group as a context for peer group mentoring”. In Peer-Group Mentoring for Teacher Development, edited by H. L. T. Heikkinen, H. Jokinen and P. Tynjälä, 112-120. New York: Routledge.

Kaunisto, S.-L., E. Estola, and M. Leiman. 2013. “'I've Let Myself Get Tired'—One Teacher's Self-Reflection Process in a Peer Group." Reflective Practice 14: 406-419. doi:10.1080/14623943.2013.767236.

Kelchtermans, G. 1996. “Teacher Vulnerability: Understanding its Moral and Political Roots.” Cambridge Journal of Education 26: 307-323.

Kelchtermans, G. 2005. “Teachers’ Emotions in Educational Reforms: Self-Understanding, Vulnerable Commitment and Micropolitical Literacy." Teaching and Teacher Education 21: 995-1006.

Kelchtermans, G. 2009. "Who I Am in How I Teach is the Message. Self-Understanding, Vulnerability and Reflection." Teachers and Teaching: Theory and Practice 15: 257-272. Kelchtermans, G. and A. Deketelaere. 2016. "The emotional dimension in becoming a teacher.” In International Handbook of Teacher Education vol. 2,, edited by J. Loughran and M.L. Hamilton, 429-461. Singapore:Springer Singapore.

Kolb, D. A. 1984. Experiential Learning: Experience as the Source of Learning and Development. Englewood Cliffs, NJ: Prentice-Hall.

Korhonen, H., Heikkinen, H.L.T., and Kiviniemi, U. 205. Peer-group mentoring in Finland. H. Heikkinen, L. Swachten, H. Akyol (Eds.), Bridge over troubled water: New perspectives on teacher induction, Pegem Akademi, Ankara, 122-146. 
Lanas, M., and G. Kelchermans. 2015. “' This has more to do with who I am than with my skills'Student teacher subjectification in Finnish teacher education. Teaching and Teacher Education 47, 22-29.

Langelotz, L. 2013. “Teachers' Peer Group Mentoring-Nine Steps to Heaven?” Education Inquiry 4: 375-394.

Lassila, E.T. 2017. Tensions in the relationships: Exploring Japanese beginning teachers' stories. Doctoral thesis. Oulu, University of Oulu. http://urn.fi/urn:isbn:9789526214764

Le Cornu, R. 2005. "Peer Mentoring: Engaging Pre-Service Teachers in Mentoring One Another." Mentoring \& Tutoring: Partnership in Learning 13: 355-366. doi:10.1080/13611260500105592

Le Maistre C \& Paré A (2010) Whatever it takes: How beginning teachers learn to survive. Teaching and Teacher Education 26(3): 559-564.

Liljestrom, A., K. Roulston, and K. deMarrais. 2007. “There's No Place for Feeling Like This in the Workplace': Women Teachers' Anger in School Settings.” In Emotion in Education, edited by P. Schutz and R. Pekrun, 267-284. Amsterdam: Academic Press.

Meijer, P. C. 2011. "The Role of Crisis in the Development of Student Teachers' Professional Identity." In Navigating in Educational Contexts-Identities and Cultures in Dialogue, edited by A. Lauriala, R. Rajala, H. Ruokamo, and O. Ylitapio-Mäntylä, 41-54. Rotterdam: Sense Publishers.

Mitchell, C. and S. Weber. 1999. Reinventing ourselves as teachers: Beyond nostalgia. London, Falmer Press.

Naysmith, J., and A. Palma. 1998. “Teachers Talking, Teachers Reflecting: How Do Teachers Reflect on Their Practice? A Case Study." Teachers and Teaching: Theory and Practice 4: 65-76.

Nias, J. 1996. "Thinking about feeling: The emotions in teaching." Cambridge Journal of Education 26(3), 293-306.

Nichols, S.L., Schutz, P.A., Rodgers, K. and K. Bilica. 2016. "Early career teachers' emotion and emerging teacher identities.” Teacher and Teaching: Theory and Practice 23(4), 1-16.

Noddings, N. 1996. "Stories and affect in teacher education." Cambridge Journal of Education 26, 435-447. doi:10.1080/0305764960260311

Noddings, N. 2001. "The Caring Teacher." In Handbook of Research on Teaching, edited by V. Richardson, 99-105. Washington DC: American Educational Research Association.

Riessman, C. K. 2008. Narratives in Social Science Research. Los Angeles: Sage Publications. 
Salmon, P., and C. K. Riessman. 2013. "Looking Back on Narrative Research: An Exchange." In Doing Narrative Research, edited by M. Andrews, C. Squire and M. Tamboukou, 197-204. 3rd ed. Thousand Oaks: SAGE.

Schonmann, S. and Kempe, A. 2010. An anthology of voices: an analysis of trainee drama teachers' monologue. British Journal of Educational Studies, 58(3), 311-329.

Shapiro, S. 2010. "Revisiting the teachers' lounge: Reflections on emotional experience and teacher identity." Teaching and Teacher Education 26, 616-621.

Silander, T. and J. Välijärvi, 2013. "The theory and practice of building pedagogical skill in Finnish teacher education." In PISA, power, and policy:The emergence of global educational governance, edited by H. Meyer and A. Benavot, 77-97. Oxford, Symposium Books.

Sitomaniemi-San, J. 2015. "Fabricating the Teacher as Researcher: a Genealogy of Academic Teacher Education in Finland." Doctoral Dissertation. Acta Universitatis Ouluensis E 157.

Spector-Mersel, G. 2010. "Narrative Research-Time for a Paradigm." Narrative Inquiry 20 (1): 204-224.

Toom A., H., Kynäslahti, L., Krokfors, R., Jyrhämä, R., Byman, K., Stenberg, K.,Maaranen and P., Kansanen. 2010. "Experiences of a research-based approach to teacher education. Suggestions for future policies.” European Journal of Education 45(2): 331-344.

Uitto, M., Jokikokko, K., \& Estola, E. 2015. "Virtual special issue on teachers and emotions in Teaching and teacher education (TATE) in 1985-2014." Teaching and Teacher Education 50: 124-135.

Uitto, M., S-L. Kaunisto, L. Syrjälä, and E. Estola. 2015. “Silenced Truths: Relational and Emotional Dimensions of a Beginning Teacher's Identity as Part of the Micropolitical Context of School.” Scandinavian Journal of Educational Research 59 (2): 1-15.

Vuorikoski, M., and M. Räisänen. 2010. “Opettajan Identiteetti ja Identiteettipolitiikat Hallintakulttuurin Murroksissa.” Kasvatus ja Aika 4 (4): 63-81.

Wang, J., and S. Odell. 2007. “An Alternative Conception of Mentor-Novice Relationships: Learning to Teach in Reform-Minded Ways as a Context." Teaching and Teacher Education 23: 473-489.

Westbury I, S., Hansén, P., Kansanen and O Björkvist. 2005. "Teacher education for research-based practice in expanded roles. Finland's experience.” Scandinavian Journal of Educational Research 49(5): 475-485.

Zeichner, K.M. (2010). Rethinking the connections between campus courses and field experiences in college- and university-based teacher education. Journal of Teacher Education, 61, 89-99. 
Zembylas, M. 2003. "Emotions and Teacher Identity: A Poststructural Perspective.” Teachers and Teaching: Theory and Practice 9 (3): 213-238.

Zembylas, M. 2004. "The emotional characteristics of teaching: An ethnographic study of one teacher." Teaching and Teacher Education 20(2), 185-201.

Zembylas, M. 2005. "Discursive Practices, Genealogies and Emotional Rules: A Poststructuralist View on Emotion and Identity in Teaching." Teaching and Teacher Education 21: 935-948.

Zembylas, M. 2007. "Reframing emotion in education through lenses of parrhesia and care of the self." Studies in Philosophy of Education 26 (4), 319-333.

Zembylas, M. 2008. "Engaging with Issues of Cultural Diversity and Discrimination through Critical Emotional Reflexivity in Online Learning.” Adult Education Quarterly 59 (1): 6182. $10.1177 / 0741713608325171$

Zembylas, M. 2012. "Manifestations of Greek-Cypriot Teachers' Discomfort toward a Peace Education Initiative: Engaging with Discomfort Pedagogically." Teaching and Teacher Education 28 (8): 1071-1082. 10.1016/j.tate.2012.06.001 